\title{
Relationships among white-tailed deer density, harvest, and landscape metrics in TN, USA
}

\author{
Heidi L. Adams ${ }^{1} \cdot$ Robert E. Kissell Jr ${ }^{2}$ (D) $\cdot$ Daryl Ratajczak ${ }^{3} \cdot$ Edward L. Warr $^{4} \cdot$ Roger D. Applegate $^{5} \cdot$ Lynn Barrett $^{5}$. \\ Tabitha Lavacot ${ }^{5} \cdot$ David Graves $^{6}$
}

Received: 22 February 2019 / Revised: 16 December 2019 / Accepted: 28 December 2019 / Published online: 15 January 2020

(C) The Author(s) 2020

\begin{abstract}
Landscape and harvest indices are frequently used to represent white-tailed deer (Odocoileus virginianus) density. However, the relationship between deer density and specific landscape indices is unclear. Harvest is another metric often used to estimate deer density. Our objective was to model the relationship among deer density, landscape metrics, and harvest density of deer in TN, USA. We estimated deer density across 11 regions in 2011 using distance sampling techniques. We developed 18 a priori models to assess relationships among deer density, harvest density, and landscape metrics. Estimates of deer density ranged from 1.85 to $19.99 \mathrm{deer} / \mathrm{km}^{2}$. Deer density was best predicted by harvest density and harvest density + percent woody area. However, harvest density was the only important variable in predicting deer density $\left(\Sigma \omega_{i}=0.700\right)$. Results of this study emphasize the significance of harvest density in deer management. While the importance of harvest as a management tool for deer is likely to increase as landscapes are fragmented and urbanized, specific management guidelines should be based upon deer densities and landscape metrics when they are important.
\end{abstract}

Keywords Deer density $\cdot$ Deer harvest $\cdot$ Landscape metrics $\cdot$ Odocoileus virginianus $\cdot$ White-tailed deer

\section{Introduction}

Human-related causes of increased ungulate populations in Europe and eastern North America include a decrease in the

Electronic supplementary material The online version of this article (https://doi.org/10.1007/s10344-019-1353-8) contains supplementary material, which is available to authorized users.

Robert E. Kissell, Jr

rkissell@tntech.edu

1 School of Agricultural Sciences and Forestry, Louisiana Tech University, P. O. Box 10138, Ruston, LA 71272, USA

2 Department of Biology, Tennessee Tech University, P. O. Box 5063, Cookeville, TN 38505, USA

3 US Department of Agriculture, Forest Service, 11 Forest Lane, Santa Fe, NM 87604, USA

4 Aerial Infrared Resources, 115 Creek Lane, Cookeville, TN 38506 , USA

5 Tennessee Wildlife Resources Agency, P. O. Box 41489, Nashville, TN 37204, USA

6 Arkansas Game and Fish Commission, 1201 N. Highway 49, Brinkley, AR 72021, USA number of hunters, climate change, increased number of people in urban areas, management for increased population sizes in rural areas, and land use changes (Maillard et al. 2010). The number of hunters has declined over time as people have developed other social and cultural interests (Enck et al. 2000 ). Only $5 \%$ of the population in the USA (US Department of the Interior 2016) and $0.5 \%$ of the population in Europe hunts (Reimoser and Reimoser 2016). Climate change has produced warmer winters, and more animals survive as a result (Maillard et al. 2010; Davis et al. 2016). A trend to live in urban areas has left much of the rural land undeveloped thereby providing more ungulate habitat (Apollonio et al. 2010). Rural inhabitants manage for increased ungulate populations to provide for economic opportunities given the declining number in people and associated economics (Apollonio et al. 2010). Land use, which is related to the aforementioned causes, can provide a landscape level understanding to match the distributions of ungulates. Landscape varies spatially and temporally, and little work has been conducted (Roseberry and Woolf 1998; Lovely et al. 2013) at the landscape scale to understand these relationships. Previous research indicated the importance of landscape metrics, such as amount of forest edge for deer (Plante et al. 
2004) and habitat fragmentation and diversity for white-tailed deer (Odocoileus virginianus; Quinn et al. 2013), both of which are influenced by land use, in predicting population densities.

Harvest, or bag, is the most common metric used to track hunted ungulate populations (Roseberry and Woolf 1991; Apollonio et al. 2010). However, most studies have demonstrated this relationship at a local or site-level and not a landscape scale (McCullough 1979; Hagen et al. 2018). Managing for maximum sustained yield and incorporating harvest of females results in a reduction in the total population given a sufficient number of females is harvested (Downing 1981; Demarais and Zaiglin 1988).

Not unlike many big game program objectives, TN's objective for white-tailed deer (Odocoileus virginianus; hereafter "deer") populations across the state is to balance the biological and social carrying capacities (Kelly et al. 2019). Human population growth is increasing in $\mathrm{TN}$, as elsewhere, resulting in urban sprawl and a reduction in habitat for wildlife (Robinson et al. 2005). Concurrent with habitat loss is an expectation by sportsmen to maintain a harvestable population (biological carrying capacity) of deer while minimizing loss of plant diversity, crop damage, and deer-vehicle collisions (social carrying capacity). As landscapes change over time, a model predicting population density of deer to compare with the biological and social carrying capacities is needed to manage this species. Therefore, our objective was to model the relationship among deer density, harvest density, and landscape metrics in TN, USA. We hypothesized landscape characteristics, specifically density of woody edge, percent forested, and harvest served as predictors of deer density at the landscape level.

\section{Materials and methods}

\section{Study area}

TN lies in the southeastern region of the USA (latitude $34^{\circ} 59^{\prime}$ $\mathrm{N}$ to $36^{\circ} 41^{\prime} \mathrm{N}$; longitude $81^{\circ} 39^{\prime} \mathrm{W}$ to $90^{\circ} 19^{\prime} \mathrm{W}$ ) covering approximately $109,000 \mathrm{~km}^{2}$. TN may be divided into 6 major physiographic regions (west to east), i.e., East Gulf Coastal Plain, Highland Rim, Central Basin, Cumberland Plateau, Ridge and Valley, and Unaka Mountains. Counties were assigned to the physiographic region in which they occurred. Counties that contained $>1$ physiographic region were assigned to the region with the greatest area in that county. The resulting sub-regions (Griffith et al. 2012; TN Climatological Service 2013; Tennessee Federal GIS Users Group 2013) were East Gulf Coastal Plain west (EGCP-W) and east (EGCP-E), Highland Rim north (HR-N), central (HR-C), and south (HR-S), Central Basin north (CB-N), central (CB-C), and south (CB-S), Cumberland Plateau (CP),
Ridge and Valley (RV), and Unaka Mountains-Ridge and Valley (UMRV; Fig. 1). By making use of the sub-regions based on physiographic regions allowed us to sample areas with similar habitats.

\section{Sampling and field procedures}

We used a multivariate regression approach to assess the relationship among residual (i.e., after harvest) deer density (response variable), harvest density, and landscape metrics (predictive variables). Deer density was used as the response variable instead of an index of density because it was the direct result of vital rates, and indices rely on critical and unlikely assumptions regarding detection probabilities (Anderson 2001). We used a random sampling design for density estimation using transects as replicates (Buckland et al. 2001) within each sub-region. We randomly selected 3 secondary roads in each county to be used as transects $(n=285)$. Transects were at least $0.5 \mathrm{~km}$ apart to maintain independence. We sampled transects beginning $0.5 \mathrm{~h}$ after sunset and ended sampling by $0200 \mathrm{~h}$; transects were not sampled when raining. Each transect was sampled once between 1 February and 4 April 2011. One observer stood in the back of a pickup truck driven 8$16 \mathrm{~km} / \mathrm{h}$ and surveyed one side of the transect using a ProTech Thermal-Eye 250D thermal imager to locate deer. Two additional people were in the back of the truck; one person operated a spotlight and aided with taking measurements, and one recorded data. When a group of deer was located, we measured the perpendicular distance from the road to the center of the group or the location where the group was first sighted with a rangefinder. We recorded group size, time, and the vehicle location using Universal Transverse Mercator coordinates with a GPS unit for each group observed.

We used Program Distance 6.0 to estimate deer density for each sub-region (Buckland et al. 2001). We set the sampling fraction to 0.5 because we sampled only one side of each transect. We modeled densities based on sample sizes greater than the minimum recommended by Buckland et al. (2001). Landscapes within sub-regions were different across the state, and different models were likely better suited on estimating density in some sub-regions than others. Therefore, we used the half-normal, uniform, and hazard rate key functions in conjunction with cosine, simple polynomial, hermite polynomial, and no series expansions. We right-truncated $5-10 \%$ of the data to improve model fit (Buckland et al. 2001). We calculated the Akaike Information Criterion value corrected for small sample size (AIC ; Akaike 1973), $\Delta \mathrm{AIC}_{\mathrm{c}}$ value, a density estimate, upper and lower $95 \%$ confidence levels for density estimates, $\chi^{2}$ goodness of fit statistic, coefficient of variation, and probability of detection for each model. We selected the best model based on the minimum $\mathrm{AIC}_{\mathrm{c}}$ value.

Statewide harvest seasons were divided into 3 general types, i.e., archery, muzzleloader, and gun. Harvest season, 


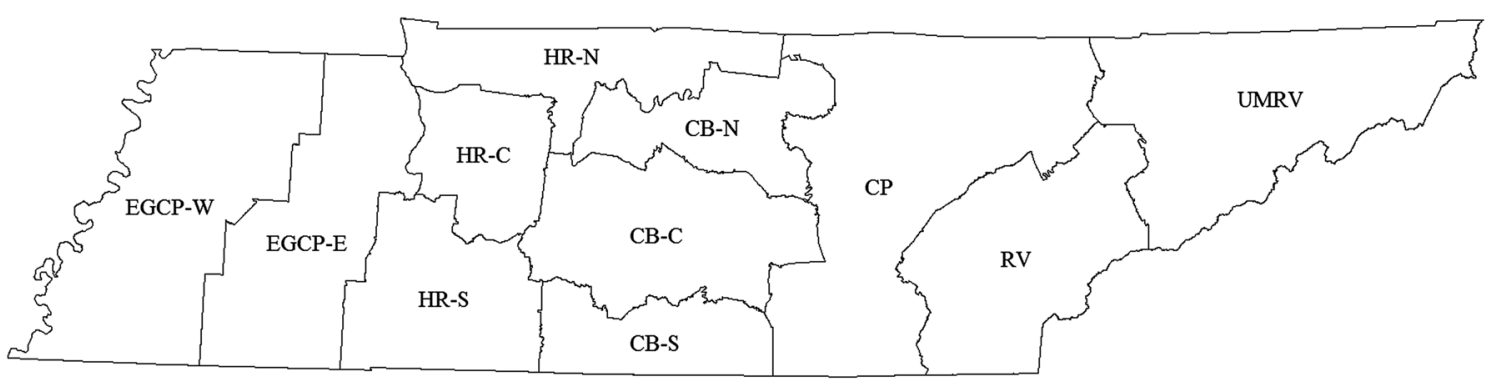

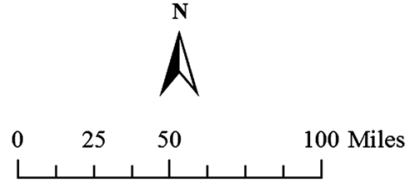

Fig. 1 East Gulf Coastal Plain (west, EGCP-W; east, EGCP-E), Highland Rim (north, HR-N; central, HR-C; south, HR-S), Central Basin (north, CB-N; central, CB-C; south, CB-S), Cumberland Plateau (CP), Ridge and

across all 3 types, ran from the third Saturday in September through the first Sunday in January. Two young sportsman hunts were open across 1 weekend before and 1 weekend following the gun season, wherein no other hunting was allowed; harvest from this hunt was traditionally minimal. Three harvest management units having different bag limits were used to provide management relative to the perceived deer density. The western two-thirds of the state were in the liberal management unit and, in addition to a 3-buck limit per season, this management unit allowed 3 does per day to be taken; the other 2 units allowed 4-10 does per season depending upon the unit (Yoest et al. 2012). Each hunter harvested an average of 1.9 deer. The harvest regime, therefore, was effectively the same across the state.

Successful deer hunters in TN are required to check their harvest with the TN Wildlife Resources Agency (TWRA). During the 2010-2011 hunting season, animals were checked using 1 of 2 approved methods: (1) check stations (> 800 locations throughout the state) or (2) internet check. Harvest data collected included date of harvest, location of kill (e.g., county or Wildlife Management Area), type of weapon used, sex of harvested deer, and number of antler points if the animal was male.

We developed a list of landscape variables; we thought would have a strong influence on deer density and were found to be important in other studies (e.g., Bobek et al. 1984; Gaudette and Stauffer 1988; Roseberry and Woolf 1998; Anderson et al. 2001; Plante et al. 2004; Long et al. 2005; Pettorelli et al. 2007; Munro et al. 2012). For each of the 95 counties in TN, we obtained data for the 2010 human population size (urban, rural, total; United States Census Bureau 2013a; TN Advisory Commission on Intergovernmental Relations 2013), land area, roads (United States Census Bureau 2013b), public land ownership, and land cover (open, urban, woodland; TN Federal GIS Users Group

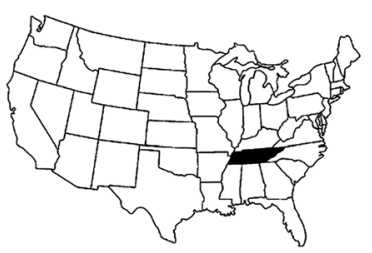

Valley (RV), and Unaka Mountains-Ridge and Valley (UMRV) regions in TN, USA. County classification based on the physiographic region that covers the greatest area within each county

2013). Slope data were obtained from the Natural Resources Conservation Service Geospatial Data Gateway (NRCS 2013). Using ArcGIS 10.2.2 (ESRI 2014), we calculated the 2010 human population size in rural areas for each county by subtracting the urban population from the total. We calculated percent public land by dividing the area of public land by the total land area of each county and multiplying by 100 . Because deer are thought to respond to landscape metrics beyond the extent of the home range (Kie et al. 2002), matching landscape scale density estimates to landscape scale metrics was appropriate.

We determined the total area and total perimeter to calculate perimeter-area ratio representative of an edge metric. Number of patches and median patch size for agricultural areas, pastures and grasslands, urban, deciduous woodlands, coniferous woodlands, and mixed woodlands for each county (ESRI 2014) were used to calculate the ratio of edge between open (agricultural, pasture, and grassland combined) and urban areas, open and woodland (deciduous, coniferous, and mixed combined) areas, and urban and woodland areas; these metrics were also representative of edge at a finer scale than simple perimeter-area ratio. We calculated percent urban land cover and percent rural land cover (open and woodland combined) by dividing each respective land cover class by the total land area of each county and multiplying by 100 . Average slope for each county was calculated based on $30 \mathrm{~m}$ digital elevation models in ArcGIS.

\section{Statistical analyses}

We reduced this predictive variable set by removing one of each correlated variable pair $(p>0.5)$. We performed linear regression using SAS PROC REG (SAS Institute 2011) to model the relationship among estimated deer density (dependent variable) and landscape metrics, deer harvest (Table 1), 
Table 1 White-tailed deer harvest data from the 2010-2011 and 2011-2012 hunting seasons for each sub-region in TN, USA. Data for total deer harvested and antlered deer harvested was presented

\begin{tabular}{|c|c|c|c|c|c|}
\hline \multirow[t]{2}{*}{ Sub-region } & \multirow[t]{2}{*}{ No. of counties } & \multicolumn{2}{|c|}{ Deer harvest, 2010-2011 } & \multicolumn{2}{|c|}{ Deer harvest, 2011-2012 } \\
\hline & & Total & Antlered & Total & Antlered \\
\hline East Gulf Coastal Plain-west & 11 & 20,517 & 9572 & 19,375 & 9330 \\
\hline East Gulf Coastal Plain-east & 8 & 24,010 & 10,504 & 23,799 & 10,883 \\
\hline Highland Rim-north & 6 & 12,295 & 5728 & 12,175 & 5818 \\
\hline Highland Rim-central & 4 & 8307 & 3952 & 7955 & 3872 \\
\hline Highland Rim-south & 6 & 11,916 & 5813 & 13,336 & 6355 \\
\hline Central Basin-north & 6 & 9352 & 4681 & 9562 & 5007 \\
\hline Central Basin-central & 8 & 15,524 & 7792 & 15,709 & 8175 \\
\hline Central Basin-south & 4 & 14,594 & 6679 & 14,597 & 7115 \\
\hline Cumberland Plateau & 17 & 18,660 & 10,321 & 19,250 & 11,395 \\
\hline Ridge \& Valley & 10 & 11,075 & 5533 & 10,775 & 5838 \\
\hline Unaka Mountains-Ridge \& Valley & 15 & 16,568 & 9287 & 17,141 & 10,416 \\
\hline
\end{tabular}

and total human population density (independent variables, Table 2). We calculated $\mathrm{AIC}_{\mathrm{c}}$ values for each of 18 models and used the minimum $\mathrm{AIC}_{\mathrm{c}}$ value to select the best model. Models with $\Delta \mathrm{AIC}_{\mathrm{c}} \leq 2.0$ were considered competing models. We calculated the weight $\left(\omega_{i}\right)$ of each competing model based on $\triangle \mathrm{AIC}_{\mathrm{c}}$ values. Because there was no clearly superior model (i.e., $\omega_{\mathrm{i}}>0.9$ ), we model-averaged parameter estimates (Burnham and Anderson 2002).

\section{Results}

Reported deer harvest for the 2010-2011 deer season was 168,044 deer, and approximately half of all harvested deer $(79,862)$ were antlered. We sampled 285 transects ranging 5.3-34.6 km in length and observed 3564 deer in 966 clusters 1 February-4 April 2011. Each model exhibited an acceptable fit (goodness-of-fit $p>0.05$ ). Precision ranged from 0.198 (CP) to 0.327 (HR-N). Probability of detection ranged from
0.325 (EGCP-E) to 0.711 (HR-S). Estimated deer density ranged from $1.85 \mathrm{deer} / \mathrm{km}^{2}$ (EGCP-W) to $19.99 \mathrm{deer} / \mathrm{km}^{2}$ (CB-S, Table 3).

Harvest density was the primary variable in competing models predicting deer density in 2011 (Table 4). Given the great potential that the system was not operating in a linear fashion but instead in a non-linear and non-parametric fashion, we conducted modeling of the data and found the linear (i.e., parametric) models were ranked, via AIC, much higher than the non-linear (i.e., spline) models (results of this analysis provided in Online resource 1). Moreover, harvest was yet the best predictor of density. The non-linear, non-parametric models ranked far below the linear models. The best model was $>2.5$ times more than likely to accurately predict deer density than the second best model (harvest density + percent woody area). The top model also accounted for $50 \%$ of the variation predicting density (Fig. 2). Averaged across all models, harvest density was the only important variable explaining deer density $\left(\Sigma \omega_{i}=0.700\right.$, Table 5$)$ and did not include zero in the $95 \%$ confidence intervals.
Table 2 List of landscape variables used to determine the relationship between white-tailed deer density in TN, USA, 2011

\begin{tabular}{|c|c|c|}
\hline Variable & Abbreviation & Description \\
\hline Deer harvest & Harvest & Number of deer harvested/sq. km during 2010-2011 hunting season \\
\hline Average slope & Slope & Average slope by county based on $30 \mathrm{~m}$ elevation maps ${ }^{\mathrm{a}}$ \\
\hline Open-woody edges & Owedge & Density of open-woody edges in each county $(\mathrm{km} / \mathrm{sq} . \mathrm{km})^{\mathrm{a}}$ \\
\hline Woody patches & Woodpatch & $\begin{array}{l}\text { Number of woody patches/sq. km; includes deciduous, coniferous, } \\
\text { and mixed forest types }{ }^{\mathrm{a}}\end{array}$ \\
\hline Percent woody area & Perwood & $\begin{array}{l}\text { Amount of woody area in each county/total county land area; } \\
\text { includes deciduous, coniferous, and mixed forest types }{ }^{\mathrm{a}}\end{array}$ \\
\hline $\begin{array}{r}\text { Rural human } \\
\text { population }\end{array}$ & Ruralpop & Number of people/sq. km based on 2010 census data ${ }^{\text {b }}$ \\
\hline Roads & Roads & Density of roads in each county $(\mathrm{km} / \mathrm{sq} . \mathrm{km})^{\mathrm{c}}$ \\
\hline
\end{tabular}

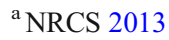

${ }^{\mathrm{b}}$ United States Census Bureau 2013a

${ }^{\mathrm{c}}$ United States Census Bureau 2013b 
Table 3 Distance sampling results of white-tailed deer by sub-region in TN, USA, 2011, including model, number of parameters $(K)$, Akaike's Information Criterion (AIC), $\triangle$ AIC, estimated deer density $\left(\right.$ deer $/ \mathrm{km}^{2}$; $D)$, and probability of detection $(P)$

\begin{tabular}{lllll}
\hline Sub-region & Model $^{\mathrm{a}}$ & $K$ & $D$ & $P$ \\
\hline East Gulf Coastal Plain-west & HN & 1 & 1.846 & 0.5217 \\
East Gulf Coastal Plain-east & HRSP & 2 & 5.849 & 0.3249 \\
Highland Rim-north & HR & 2 & 8.24 & 0.3683 \\
Highland Rim-central & HNC & 2 & 10.692 & 0.4372 \\
Highland Rim-south & UHP & 1 & 4.131 & 0.7111 \\
Central Basin-north & UC & 1 & 9.953 & 0.5242 \\
Central Basin-central & HR & 2 & 6.731 & 0.5672 \\
Central Basin-south & HR & 2 & 19.985 & 0.478 \\
Cumberland Plateau & UC & 1 & 3.295 & 0.5653 \\
Ridge and Valley & HN & 1 & 2.538 & 0.4688 \\
Unaka Mountains-Ridge \& Valley & HR & 2 & 2.527 & 0.3522 \\
\hline
\end{tabular}

${ }^{a} H N$ half-normal distribution, no adjustments; $H N C$ half-normal distribution, cosine adjustment; HNSP half-normal distribution, simple polynomial adjustment; $H N H P$ half-normal distribution, hermite polynomial adjustment; $U C$ uniform distribution, cosine adjustment; USP uniform distribution, simple polynomial adjustment; UHP uniform distribution, hermite polynomial adjustment; $H R$ hazard rate distribution, no adjustment; HRSP hazard rate distribution, simple polynomial adjustment

\section{Discussion}

Our results indicated that residual deer density was best predicted by density of deer harvested. Other studies reporting harvest as a predictive variable for deer density have been disparate. Hansen et al. (1986) determined deer population

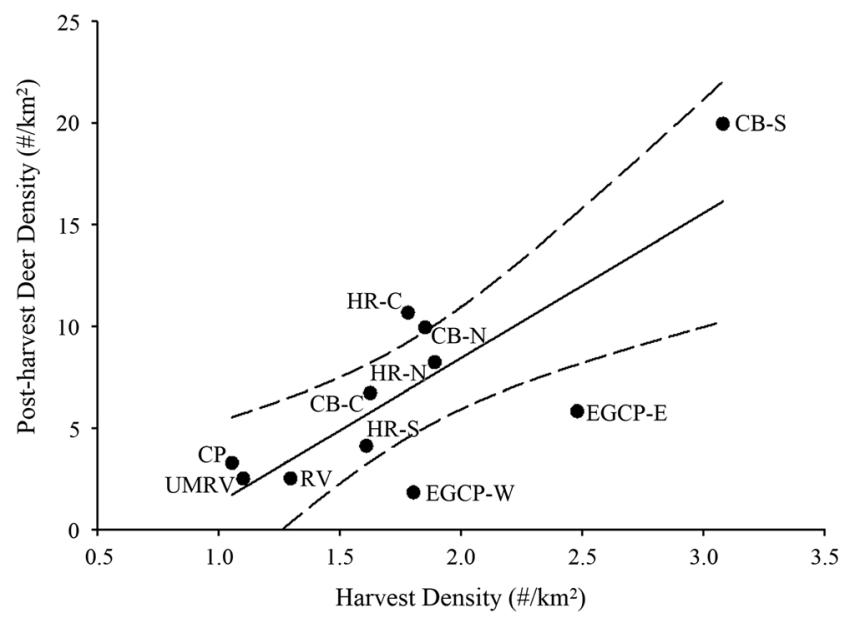

Fig. 2 Regression between harvest density $\left(\right.$ deer $\left./ \mathrm{km}^{2}\right)$ and deer density $\left(\right.$ deer $\left./ \mathrm{km}^{2}\right)$ in TN, USA, 2011. Solid line represents the predicted relationship and the dashed lines represent $95 \%$ confidence intervals

size in IL was positively correlated with harvest, while Pettorelli et al. (2007) found no correlation between deer density and the number of deer harvested per day in Québec. Roseberry and Woolf (1998) speculated statewide pre-hunt deer density was regulated by harvest, even though density was considered low (e.g., 4-5 deer $/ \mathrm{km}^{2}$ ). Five of our subregions were estimated to have densities $<5 \mathrm{deer} / \mathrm{km}^{2}$, and these occurred in eastern and western portions of the state (the EGCP-W, RV, UMRV, CP, and HRS sub-regions had densities of $1.85,2.54,2.53,3.30$, and $4.13 \mathrm{deer} / \mathrm{km}^{2}$, respectively). Eastern regions of TN are known to contain lower
Table 4 Models examined to predict white-tailed deer density $\left(\right.$ deer $\left./ \mathrm{km}^{2}\right)$, number of parameters in each model $(K)$, Akaike's information criterion corrected for small samples $\left(\mathrm{AIC}_{\mathrm{c}}\right), \Delta \mathrm{AIC}_{\mathrm{c}}$, model weights based on $\mathrm{AIC}_{\mathrm{c}}$ values, and model coefficient of determination $\left(R^{2}\right)$ based on selected landscape metrics across TN, USA, 2011

\begin{tabular}{llrrrr}
\hline Model & $K$ & \multicolumn{1}{c}{$\mathrm{AIC}_{\mathrm{c}}$} & \multicolumn{1}{c}{$\Delta \mathrm{AIC}_{\mathrm{c}}$} & \multicolumn{1}{c}{$\omega_{\mathrm{i}}$} & \multicolumn{2}{l}{$R^{2}$} \\
\hline Harvest & 3 & -6.101 & 0.000 & 0.415 & 0.504 \\
Harvest + perwood & 4 & -4.222 & 1.879 & 0.162 & 0.543 \\
Owedge & 3 & -3.755 & 2.346 & 0.129 & 0.386 \\
Slope & 3 & -2.469 & 3.632 & 0.068 & 0.310 \\
Harvest + slope & 4 & -1.608 & 4.493 & 0.044 & 0.420 \\
Harvest + owedge & 4 & -1.599 & 4.502 & 0.044 & 0.420 \\
Woodpatch & 3 & -0.941 & 5.160 & 0.031 & 0.207 \\
Harvest + roads & 4 & -0.924 & 5.177 & 0.031 & 0.383 \\
Roads & 3 & 0.536 & 6.637 & 0.015 & 0.093 \\
Ruralpop + owedge & 4 & 0.937 & 7.038 & 0.012 & 0.269 \\
Ruralpop & 3 & 0.981 & 7.082 & 0.012 & 0.055 \\
Roads + owedge & 4 & 1.165 & 7.266 & 0.011 & 0.254 \\
Perwood & 3 & 1.484 & 7.585 & 0.009 & 0.011 \\
Ruralpop + woodpatch + owedge & 5 & 1.536 & 7.637 & 0.009 & 0.547 \\
Perwood + woodpatch & 4 & 3.292 & 9.393 & 0.004 & 0.095 \\
Ruralpop + woodpatch & 4 & 4.285 & 10.386 & 0.002 & 0.009 \\
Ruralpop + perwood & 4 & 6.132 & 12.233 & 0.001 & -0.172 \\
Harvest + ruralpop + slope + perwood + & 9 & 161.674 & 167.775 & 0.000 & 0.750 \\
$\quad$ woodpatch + roads + owedge & & & & & \\
\hline & & & & & \\
\hline
\end{tabular}


Table 5 Model-averaged parameter estimates, standard errors (SE), lower and upper 95\% confidence levels (LCL, UCL), and relative importance of each variable from linear regression $\left(\Sigma \omega_{i}\right)$ predicting density of whitetailed deer in TN, USA, 2011

\begin{tabular}{lccccc}
\hline Variable & Parameter estimate & SE & LCL & UCL & $\Sigma \omega_{i}{ }^{a}$ \\
\hline Intercept & -0.087 & 1.242 & -2.521 & 2.347 & 1.000 \\
Harvest density & 0.628 & 0.294 & 0.52 & 1.203 & 0.700 \\
Open-woody edges & 0.251 & 0.245 & -0.229 & 0.732 & 0.205 \\
Percent woody area & 0.267 & 0.284 & -0.289 & 0.822 & 0.176 \\
Average slope & -0.048 & 0.055 & -0.156 & 0.060 & 0.111 \\
Roads & -0.006 & 0.029 & -0.064 & 0.051 & 0.057 \\
Woody patches & -0.006 & 0.006 & -0.018 & 0.007 & 0.047 \\
Rural human population & $-4.3 \mathrm{E}-04$ & 0.002 & -0.004 & 0.003 & 0.037 \\
\hline
\end{tabular}

${ }^{\text {a }}$ Importance values were calculated by summing model weights across all models in which the variable occurred quality deer habitat, and deer in this part of the state are dependent upon unpredictable mast production (Johnson et al. 1995; Ryan et al. 2004) which would explain the lower observed deer densities.

Lack of association between density and any of the selected landscape metrics was surprising. The implication would be that deer respond to harvest more numerically than to habitat. Some areas in TN, those in central TN in particular, experienced much human population growth over the last two decades, and with that growth fragmentation of the landscape occurred. Western and eastern portions of the state experienced little human population growth by comparison. Harvest in some sub-regions of western and eastern TN demonstrated up to $49 \%$ harvest of the population during this study. One possible explanation for our lack of finding any landscape metrics as important is that harvest of the population was additive to the natural mortality that occurs through disease (e.g., epizootic hemorrhagic disease) and predation, thereby holding the population low enough such that habitat factors were not quite sufficient to be statistically identified. This suggests the population was below carrying capacity and just above the point of maximum growth. In the central portion of the state where human population was growing and fragmentation was increasing, carrying capacity may be such that the deer population was responding numerically to the improved habitat but had not reached a point where habitat is a factor. These sub-regions demonstrated low proportions of the populations being harvested. In short, we think two possible processes are in play. First, fragmentation has been occurring in the central portion of the state at such a rate that the deer population has not yet reached a level to where the habitat factors are substantially affecting population growth. These sub-regions do not have a high percentage of the population harvested. The eastern and western areas do have a high proportion of the population harvested (approaching 50\% in some cases) and these are likely kept well below $K$, such that the harvest is more important than landscape metrics in explaining the results.

Because deer-not just white-tailed (Alverson et al. 1988; Anderson et al. 2001), but also other species (i.e., black-tailed
[Odocoileus hemionus columbianus; Kremsater and Bunnell 1992], sika [Cervus nippon; Takatsuki 1989], roe [Hansson 1994; Tufto et al. 1996]) — are characteristically edge species, it would be expected that the amount of open-woody edge in an area would better predict deer density (Waller and Alverson 1997). We found, however, open-woody edge was secondary to harvest density and did not contribute to the model predicting deer density.

Previous research indicates deer prefer forested edges (Aulak and Babińska-Werka 1990; Marques et al. 2001; Torres et al. 2012). Home range selection is strongly based on landscape metrics, including edge (Beier and McCullough 1990; Kie et al. 2002; Fulbright and Ortega 2006). Moreover, landscape metrics, including edge, have been tied to reproductive fitness (McLoughlin et al. 2007; Miyashita et al. 2008). As edge has increased through landscape, fragmentation deer have likely selected smaller home ranges because of more available forage and responded by increasing population size; this is supported by the highest densities being associated with areas of increasing population growth and associated fragmentation.

Based upon our results, deer populations in TN are still harvest-dependent but not influenced by landscape use. Biologists and managers will be challenged to maintain the harvest tool as the number of sportsmen and sportswomen decline in the USA (US Department of Interior et al. 2016). Models incorporating landscape metrics to track ungulate populations in both Europe and the USA have been many (Foster et al. 1997; Radeloff et al. 1999; Acevedo et al. 2011), and inclusion of landscape metrics (deCalesta and Stout 1997; Putman et al. 2011) in addition to harvest density in models to predict deer population density would be less costly than estimating population density on a regular basis. Harvest is often the only common metric collected for big game by wildlife agencies (Unsworth et al. 2002; Apollonio et al. 2010). However, when landscape metrics are not related to density, as found in this work, harvest remains an important and crucial tool (Milner et al. 2006) to manage population densities. 
Acknowledgments We also thank the numerous wildlife officers, biologists and technicians from the Tennessee Wildlife Resources Agency who assisted with data collection. Editorial assistance was provided by B. E. Flock. We also wish to thank anonymous reviewers, the Editor and Associate Editor for their recommendations and suggestions to improve this work.

Funding information Financial support for the study was provided by the Tennessee Wildlife Resources Agency using Pittman-Robertson Federal Aid in Wildlife Restoration funds.

Open Access This article is licensed under a Creative Commons Attribution 4.0 International License, which permits use, sharing, adaptation, distribution and reproduction in any medium or format, as long as you give appropriate credit to the original author(s) and the source, provide a link to the Creative Commons licence, and indicate if changes were made. The images or other third party material in this article are included in the article's Creative Commons licence, unless indicated otherwise in a credit line to the material. If material is not included in the article's Creative Commons licence and your intended use is not permitted by statutory regulation or exceeds the permitted use, you will need to obtain permission directly from the copyright holder. To view a copy of this licence, visit http://creativecommons.org/licenses/by/4.0/.

\section{References}

Acevedo P, Farfán MA, Márquz AL, Delibes-Mateos M, Real R, Vargas JM (2011) Past, present, and future of wild ungulates in relation to changes in land use. Landsc Ecol 26:19-31

Akaike H (1973) Information theory and an extension of the maximum likelihood principle. In: Petrov BN, Csáki F (eds) Proceedings of the Second International Symposium on Information Theory. Akadémiai Kiadó, Budapest, Hungary, pp 267-281

Alverson WS, Waller DM, Solheim SL (1988) Forests too deer: edge effects in northern Wisconsin. Conserv Biol 2:348-358

Anderson DR (2001) The need to get the basics right in wildlife field studies. Wildlife Soc B 29:1294-1297

Anderson RC, Corbett EA, Anderson MR, Corbett GA, Kelley TM (2001) High white-tailed deer density has negative impact on tallgrass prairie forbs. Journal of the Torrey Botanical Soc 128: 381-392

Apollonio M, Andersen R, Putman RJ (2010) European ungulates and their management in the 21 st century. Cambridge University Press, Cambridge, UK

Aulak W, Babińska-Werka J (1990) Use of agricultural habitats by roe deer inhabiting a small forest area. Acta Theriol 35:121-1278

Beier P, McCullough DR (1990) Factors influencing white-tailed deer activity patterns and habitat use. Wildllife Mono 109:1-59

Bobek B, Boyce MS, Kosobucka M (1984) Factors affecting red deer (Cervus elaphus) population density in southeastern Poland. J Appl Ecol 21:881-890

Buckland ST, Anderson DR, Burnham KP, Laake JL, Borchers DL, Thomas L (2001) Introduction to distance sampling. Oxford University Press, New York, New York, USA

Burnham KP, Anderson DR (2002) Model selection and multimodel interference: a practical information-theoretic approach, Second edn. Springer-Verlag, New York, New York, New York, USA

Davis ML, Stephens PA, Kjellander P (2016) Beyond climate envelope projections: roe deer survival and environmental change. J Wildl Manag 80:452-464
deCalesta DS, Stout SL (1997) Relative deer density and sustainability: a conceptual framework for integrating deer management with ecosystem management. Wildlife Soc B 25:252-258

Demarais S, Zaiglin RF (1988) Doe harvest effects. Rangelands 10:220 222

Downing RL (1981) Deer harvest sex ratios: a symptom, a prescription, or what? Wildlife Soc B 9:8-13

Enck JW, Deker DJ, Brown TL (2000) Status of hunter recruitment and retention in the United States. Wildlife Soc B 28:817-824

Environmental Systems Resource Institute (ESRI) (2014) ArcMap 10.2.2. Redlands, California, USA

Foster JR, Roseberry JL, Woolf A (1997) Factors influencing efficiency of white-tailed deer harvest in Illinois. J Wildl Manag 61:1091-1097

Fulbright TE, Ortega JA (2006) White-tailed deer habitat: ecology and management on rangelands. Texas A\&M University Press, College Station, Texas

Gaudette MT, Stauffer DF (1988) Assessing habitat of white-tailed deer in southwestern Virginia. Wildlife Soc B 16:284-290

Griffith G, Omernick J, Azevedo S (2012) Ecoregions of Tennessee. United States Environmental Protection Agency, Atlanta, Georgia, USA <http://www.epa.gov/wed/pages/ecoregions/tn_eco.htm>. Accessed 16 September 2013

Hagen R, Haydn A, Suchant R (2018) Estimating red deer (Cervus elaphus) population size in the southern Black Forest: the role of hunting in population control. Eur J Wildl Res 64:42. https://doi.org/ 10.1007/s10344-018-1204-z,8

Hansen LP, Nixon CM, Loomis F (1986) Factors affecting daily and annual harvest of white-tailed deer in Illinois. Wildlife Soc B 14: 368-376

Hansson L (1994) Vertebrate distributions relative to clear-cut edges in a boreal forest landscape. Landsc Ecol 9:105-115

Johnson AS, Hale PE, Ford WM, Wentworth JM, French JR, Anderson OF, Pullen GB (1995) White-tailed deer foraging in relation to successional stage, overstory type and management of southern Appalachian forests. Am Midl Nat 133:18-35

Kelly J, Layton B, Miller B, Chandler B, Harden C, Gibbs D, Grove D, Konyndyk L, McCord M, Skogland R (2019) Deer Management in Tennessee: 2019-2023 A strategic plan for the systems, processes, protocols, and programs pertaining to the management of whitetailed deer in Tennessee. Tennessee Wildlife Resources Agency, Nashville, Tennessee, USA

Kie JG, Bowyer RT, Nicholson MC, Boroski BB, Loft ER (2002) Landscape heterogeneity at differing scales: effects on spatial distribution of mule deer. Ecology 83:530-544

Kremsater LL, Bunnell FL (1992) Testing responses to forest edges: the example of black-tailed deer. Can J Zool 70:2426-2435

Long ES, Diefenbach DR, Rosenberry CS, Wallingford BD, Grund MD (2005) Forest cover influences dispersal distance of white-tailed deer. J Mammal 86:623-629

Lovely KR, McShea WJ, Lafon NW, Carr DE (2013) Land parcelization and deer population densities in a rural county of Virginia. Wildlife Soc B 37:360-367

Maillard D, Gaillard J, Hewison M, Ballon P, Duncan P, Loison A, Toïgo C, Baubet E, Bonenfant C, Garel M, Saint-Andrieux C (2010) Ungulates and their management in France. In: Apollonio M, Andersen R, Putnam R (eds) European ungulates and their management in the 21st century. Cambridge University Press, New York, New York, USA, pp 441-474

Marques FFC, Buckland ST, Goffin D, Dixon CE, Borchers DL, Mayle BA, Peace AJ (2001) Estimating deer abundance from line transect surveys of dung: sika deer in southern Scotland. J Appl Ecol 38: 349-363

McCullough DR (1979) The George Deer Reserve deer herd. The Blackburn Press, Caldwell, New Jersey, USA

McLoughlin PD, Gaillard JM, Boyce MS, Bonenfant C, Messier F, Duncan P, Delorme D, Moorter BV, Säid S, Klein F (2007) 
Lifetime reproductive success and composition of the home range in a large herbivore. Ecol 88:3192-3201

Milner JM, Bonenfant C, Mysterud A, Gaillard JM, Csányi S, Stenseth NC (2006) Temporal and spatial development of red deer harvesting in Europe: biological and cultural factors. J Appl Ecol 43:721-734

Miyashita T, Suzuki M, Ando D, Fujita G, Ochiai K, Asada M (2008) Forest edge creates small-scale variation in reproductive rate of sika deer. Popul Ecol 50:111-120

Munro KG, Bowman J, Fahrig L (2012) Effect of paved road density on abundance of white-tailed deer. Wildl Res 39:478-487

Natural Resources Conservation Service (NRCS) (2013) Geospatial data gateway. United States Department of Agriculture, Washington, DC, USA. <http://datagateway.nrcs.usda.gov/>. Accessed 16 September 2013

Pettorelli N, Côté SD, Gingras A, Potvin F, Huot J (2007) Aerial surveys vs hunting statistics to monitor deer density: the example of Anticosti Island, Québec, Canada. Wildl Biol 13:321-327

Plante M, Lowell K, Potvin F, Boots B, Fortin MJ (2004) Studying deer habitat on Anticosti Island, Québec: relating animal occurrences and forest map information. Ecol Model 174:387-399

Putman R, Watson P, Langbein J (2011) Assessing deer densities and impacts at the appropriate level for management: a review of methodologies for use beyond the site scale. Mammal Rev 41:197-219

Quinn ACD, Williams DM, Porter WF (2013) Landscape structure influences space use by white-tailed deer. J Mammal 94:398-407

Radeloff VC, Pidgeon AM, Hostert P (1999) Habitat and population modelling of roe deer using an interactive geographic information system. Ecol Model 114:287-304

Reimoser F, Reimoser S (2016) Long-term trends of hunting bags and wildlife populations in Central Europe. Beiträge zur Jagd- und Wildforschung 41:29-43

Robinson L, Newell JP, Marzluff JM (2005) Twenty-five years of sprawl in the Seattle region: growth management responses and implications for conservation. Landsc Urban Plan 71:51-72

Roseberry JL, Woolf A (1991) A comparative evaluation of techniques for analyzing white-tailed deer harvest data. Wildl Monogr 117:359

Roseberry JL, Woolf A (1998) Habitat-population density relationships for white-tailed deer in Illinois. Wildlife Soc B 26:252-258

Ryan CW, Pack JC, Igo WK, Rieffenberger JC, Billings AB (2004) Relationship of mast production to big-game harvests in West Virginia. Wildlife Soc B 32:786-794

SAS Institute Inc (2011) 9.3 Help and Documentation. Cary, North Carolina, USA
Takatsuki S (1989) Edge effects created by clear-cutting on habitat use by sika deer on Mt. Goyo, northern Honshu, Japan. Ecol Res 4:287295

Tennessee Advisory Commission on Intergovernmental Relations (2013) County profiles. State of Tennessee Government, Nashville, Tennessee, USA <http://www.state.tn.us/tacir/county_profiles. html >. Accessed 1 October 2013

Tennessee Climatological Service (2013) Climate of Tennessee. The University of Tennessee Institute of Agriculture, Knoxville, Tennessee, USA <https://ag.tennessee.edu/climate/Documents/ Climate\%20of\%20TN.pdf>. Accessed 13 September 2013

Tennessee Federal GIS Users Group (2013) Tennessee spatial data server: an official source of Tennessee GIS data. Cookeville, Tennessee, USA. <http://www.tngis.org/index.html>. Accessed 16 October 2013

Torres RT, Virgós E, Panzacchi M, Linnell JDC, Fonseca C (2012) Life at the edge: roe deer occurrence at the opposite ends of their geographical distribution, Norway and Portugal. Mamm Biol 77:140-146

Tufto J, Andersen R, Linnell J (1996) Habitat use and ecological correlates of home range size in a small cervid: the roe deer. J Anim Ecol 65:715-724

United States Census Bureau (2013a) American factfinder. U. S. Department of Commerce, Washington, DC, USA. <http:// factfinder2.census.gov/faces/nav/jsf/pages/index.xhtml>. Accessed 19 August 2013

United States Census Bureau (2013b) Geography: TIGER/line shapefiles and TIGER/line files. U. S. Department of Commerce, Washington, DC, USA <http://www.census.gov/geo/maps-data/data/tiger-line. $\mathrm{html}>$. Accessed 22 August 2013

United States Department of the Interior, US Fish and Wildlife Service, US Department of Commerce, US Census Bureau (2016) National Survey of fishing, hunting, and wildlife-associated recreation. U.S. Department of the Interior U.S. Fish \& Wildlife Service, Washington, DC, USA

Unsworth JW, Johnson NF, Nelson LJ, Miyasaki HM (2002) Estimating mule deer harvest in southwestern Idaho. Wildlife Society B 30: 487-491

Waller DM, Alverson WS (1997) The white-tailed deer: a keystone herbivore. Wildlife Soc B 25:217-226

Yoest, C, Hunter C, Sweaney J (2012) Big game harvest report 20112012. Tennessee Wildlife Resources Agency technical report 12-09. Nashville, TN, USA

Publisher's note Springer Nature remains neutral with regard to jurisdictional claims in published maps and institutional affiliations. 